\title{
COMPARING BETWEEN PRODUCT-SPECIFIC AND GENERAL IMPULSE BUYING TENDENCY: DOES SHOPPERS' PERSONALITY INFLUENCE THEIR IMPULSE BUYING TENDENCY?
}

\author{
Chandan Parsad ${ }^{*}$, Sanjeev Prashar², and T. Sai Vijay ${ }^{3}$ \\ ${ }^{1}$ Rajagiri Business School, Rajagiri Valley P. O., \\ Kakkanad, Kochi, Kerala 682039, India \\ ${ }^{2}$ Indian Institute of Management Raipur, Atal Nagar P. O., \\ Kurru (Abhanpur), Raipur (C. G.) 493661, India \\ ${ }^{3}$ Indian Institute of Management Ranchi, Suchna Bhawan, \\ Audrey House Campus, Meur's Road, Ranchi, Jharkhand 834008, India \\ *Corresponding author: chandanparsad@gmail.com
}

Published online: 30 December 2019

To cite this article: Parsad, C., Prashar, S., and Vijay, T.S. (2019). Comparing between product-specific and general impulse buying tendency: Does shoppers' personality influence their impulse buying tendency? Asian Academy of Management Journal, 24(2), 41-61. https://doi.org/10.21315/aamj2019.24.2.3

To link to this article: https://doi.org/10.21315/aamj2019.24.2.3

\begin{abstract}
The sudden urge to buy, referred to as impulsive buying, is triggered by both a gamut of extraneous, market-related stimuli and internal psychological factors. The extant literature on this has majorly focused on the antecedents of impulsive shopping, prominent among these include traits (like sensation-seeking and impulse buying tendency or IBT), motives (utilitarian, hedonic), shoppers' resources (time and money), and marketing stimuli. Although personality is a key determinant of consumer decision-making, the role of personality traits, specially extraversion, neuroticism, and conscientiousness, in impulse buying is not conclusive. Also, there exists a need for analysing impulse buying behaviour with respect to product-specific situations rather than general IBT. The present study fills this gap by analysing the role of three personality traits on impulse buying. A scenariobased online experiment was conducted, and the sample respondents were randomly categorised into two groups. The former group had respondents with an instrument to measure their IBT in general, while the later had respondents for whom the instrument was shared with a scenario built around the product category of apparel. With the data set of 386 respondents, the study reveals that the relationships between the two personality
\end{abstract}

(C) Asian Academy of Management and Penerbit Universiti Sains Malaysia, 2019. This work is licensed under the terms of the Creative Commons Attribution (CC BY) (http://creativecommons. org/licenses/by/4.0/). 
traits-extraversion and neuroticism, and IBT-are independent of the product category. However, the influence of conscientiousness on impulsive buying tendency depends on the product category. The study concludes with managerial implications.

Keywords: extraversion, impulse buying, neuroticism, conscientiousness, impulsive buying tendency

\section{INTRODUCTION}

During the first week of October 2016, two big e-commerce giants in India came up with three-day promotional offers - Amazon and Flipkart launched "Great India Festival Sale" and "Big Billion Day Sale," respectively. During the period, two firms cumulatively sold 30.5 million products, which is much higher than the monthly sale of the two companies (Sen \& Dalal, 2016). Similarly, Alibaba had reported USD17.8 billion worth of goods sold on a single day sale (Ming, 2017). These events raise important questions about the shopping behaviour displayed by online shoppers - Why so many consumers buy products during such campaigns? Were these purchases duly planned? Or, was it triggered by promotional schemes that resulted in unplanned/impulsive buying? Earlier studies have posited that impulsive buying represents a big amount in the total purchasing volume of an individual (Dawson \& Kim, 2010; Heilman et al., 2002). In the United Kingdom, shoppers spent approximately 21.7 billion euro on impulsive buying (Global Banking \& Financial Review, 2016). While in the United States, more than onethird of the shoppers were characterised as impulsive shoppers (Criteol, 2016). According to Nicholas et al. (2001), approximately 50\% of the mall shoppers were impulsive shoppers.

Literature has established that impulsive buying is spontaneous behaviour, which can be triggered by situational factors, as well as the individual's tendency, which varies from person to person (Rook, 1987). Earlier research works on impulsive buying were mainly focused on the external factors like product features and shopping environment (Parsad et al., 2017; Stern, 1962). Later, Rook and Hoch (1985) articulated, "it is the individual, not product, who experience the impulse to consume" and hence posited that personal factors of the shoppers might play a very imperative role in impulse buying. Studies like Dittmar et al. (1995) and Silvera et al. (2008) found that young women have more tendencies to buy impulsively. While a few other studies have established that individualism, hedonism, and materialism influence shoppers' impulsive buying tendency (IBT). This is a trait that creates an urge to buy the product impulsively at the spur of the moment (Rook \& Fisher, 1995). Recent studies have recognised the various traits associated with impulsive buying. These research works have suggested that personality traits such 
as extraversion, neuroticism, and conscientious have a relationship with impulsive buying (Lucas \& Koff, 2014), which creates an urge to buy impulsively (Olsen et al., 2016; Parsad et al., 2019).

In their study, Kumar et al. (2020) observed that monotony/boredom, risk-taking behaviour, trust, persuasion, and haptics were prominent antecedents to impulsive urges, which trigger impulse buying choices. Extending the findings of Lucas and Koff(2014), Olsen et al. (2016), Parsad et al. (2019), and Thompson and Prendergast (2015), these paper have examined the impact of three main personality traitsextraversion, neuroticism, and conscientiousness on IBT in two contexts-general scenario (without specification of any product category) and specific product scenario (with fashion apparel and accessories, and defined product category). Chang (2010) and Saran et al. (2016) posited the role of shoppers' personality identities and values in their processing of information, formulation of purchase intent, and their buying decision. Further, Sarabia-Sanchez et al. (2012) have also highlighted the pertinence of linking shoppers' values with fashion shopping style while deciding retail marketing mix strategies in congruence with shoppers' psychographic profile.

Jones et al. (2003) highlighted the relative significance of examining productspecific impulse buying behaviour vis-à-vis the general IBT. The study also emphasised on examining and comparing the influence of shoppers' personality and buying behaviour across different product and product categories. Based on recommendations of earlier studies, including Jones et al. (2003), it becomes highly pertinent to analyse impulse buying behaviour with respect to productspecific situations rather than general IBT, also to determine whether consumer personality influence purchasing behaviour in the same manner or varies across the different product categories. The present study is an attempt to fill this gap by analysing the role of three personality traits on impulse buying in two different experimental situations - specific product category (apparel) and general category. Thus, the present study explores the understanding of IBT from a general to a specific situation.

Past research works have assumed IBT to be a general trait and consistent across the product categories (Rook \& Fisher, 1995; Olsen et al., 2016; Parsad et al., 2019). However, none of the studies has considered the role of these traits in impacting IBT for the product-specific scenario. This paper is a pioneer in exploring the role of product category on the relationship between select personality traits and IBT. Therefore, this research fills the gap by analysing the relationship between personality traits and IBT and examines whether this relationship is independent of the product category. 


\section{THEORETICAL BACKGROUND}

\section{Impulse Buying Tendency}

Over the years, psychologists have posited that people have varying propensity with respect to their impulsivity. Various consumer behaviour studies like Beatty and Ferrell (1998), Rook (1987), Rook and Fisher (1995), and Rook and Gardner (1993) too have demonstrated the differences among shoppers' impulsive shopping proclivity. While Rook (1987) considered this "consumer impulsivity" to be a "lifestyle trait," Rook and Fisher (1995) conceptualised "individuals" impulse shopping tendencies as a buyer trait." IBT is a measure of an individual's likelihood in indulging in "unintended, immediate, and unreflective purchase" (Jones et al., 2003). Besides the generalised perspective of the impulsive shopping tendency, Jones et al. (2003) have also noted the prevalence of product-specific IBT. Differentiating the two, this category of IBT is manifested as the tendency of shoppers to respond to sudden urges and consequently buy products of a specific category.

Prominent studies like Beatty and Ferrell (1998), and Rook and Fisher (1995) have posited that deciphering shoppers' personality traits can facilitate in comprehending their impulsive shopping tendency. Buyers with higher impulsive tendency get more influenced by marketer-initiated promotional efforts including sales promotion incentives and advertisements (Youn \& Faber, 2000). This further leads to shopping at the spur of the moment without consideration of any future consequences. Dawson and Kim (2009), and Parsad et al. (2017) observed that there exists a positive relationship between the IBT and shopping impulsively.

A personality trait is a distinctive characteristic of an individual. Different psychologists have determined various types of personality traits and that each individual can be categorised into at least one of them. In the last five decades, researchers have focused on the association between personality and shopper behaviour and hence it emerged as a prominent area of discussion (Kassarjian \& Sheffet, 1991).

\section{Personality Traits and IBT}

Extant literature has deliberated on the influence of various personality factors on shoppers' impulse buying behaviour (e.g., Atulkar \& Kesari, 2018; Bratko et al., 2013; Sun \& Wu, 2011; Sharma et al., 2010; Webster \& Crysel, 2012). Bellini et al. (2017) and Sharma et al. (2010) noted a significant positive association between shoppers' impulsiveness and their impulse buying behaviour. An earlier 
study by Verplanken and Herabadi (2001) observed a negative correlation between individuals' conscientiousness and IBT.

Olsen et al. (2016) posited that neuroticism and conscientiousness are the two most important personality traits characterising impulse buyers. The study also reflected that openness to experience has no association with IBT. Studies by Bratko et al. (2013) and Verplanken and Herabadi (2001) also noted a significant relationship between extraversion and IBT. Another big five-personality trait agreeableness was found to have an insignificant effect on IBT (Bratko et al., 2013; Verplanken \& Herabadi, 2001; Webster \& Crysel, 2012; Olsen et al., 2016). However, existing studies by Jones et al. (2003) and Chen and Wang (2016) have stated that impulsive tendencies vary with product categories and hence future studies must be undertaken to account for the product-specific impulsive tendency. This would enable better predictability of impulsive purchases.

In general, previous studies relied on general cues of IBT and ignored the productspecific IBT. Therefore, to address this gap, this study has used both general IBT and product-specific IBT. As noted in the literature, only three-personality traits of the Big Five model showed the impact on IBT. Therefore, this paper analyses the impact of extraversion, neuroticism and conscientiousness influence on both general IBT and product-specific IBT.

\section{HYPOTHESES DEVELOPMENT}

\section{Influence of Extraversion}

Carver and Scheier (2008) found that the behavioural and emotional characteristics (which include social power, emotional feelings, sociability, achievement, and motor activities) play a significant role in defining the extraversion personality trait. Normally, individuals exhibiting extraversion personality trait are friendly (Judge et al., 1999). According to Carver and Scheier (2008), these individuals also exhibit emotional characteristics like sociability, group dominance, positive emotional feeling, and goal-directedness. As Watson and Clark (1997) noted, "extraverts are more sociable but are also described as being more active and impulsive, less dysphoric, and as less introspective and self-preoccupied than introverts." Addictive and compulsive behavioural researches further suggest that the neural system refined by neurotic behaviours has significant involvement in incentive prominence attribution. This alters the sensory features of natural stimuli transforming to especially prominent stimuli that "grab the attention" and hence, are attractive and wanted, thus, tempting and guiding behaviour to a goal 
(Robinson \& Berridge, 1993). The addictive behaviour of psychological process determines impulse buying action (Jones et al., 2003). Although individuals may sometimes report that they feel bad on account of such purchase decision and will stop overspending, or become more careful, they are themselves confused by the intensity of their impulsive actions. Thus, it can be possibly explained that extraverted individuals purchase because of impulse as a manifestation of the incentive prominence attribution factor. As per Saran et al. (2016), individuals who are social, talkative, assertive, and ambitious, exhibit positive emotions for product categories like fashion apparel. Focusing on long-term perspective and value, people who are responsible, risk-averse and dependable also exert positive emotion in fashion-related shopping. Based on the above discussion, the following hypotheses are formulated:

$\mathrm{H}_{1 \mathrm{a}}$ : Extraversion will have a positive relation with IBT

$\mathrm{H}_{1 \mathrm{~b}}$ : Extraversion will have a positive relation with product specific IBT

\section{Influence of Neuroticism}

Existing studies have established a relationship between neuroticism and impulsivity. In the NEO Personality Inventory-Revised (NEO PI-R) model, "impulsiveness" is considered an aspect of neuroticism (Costa \& McCrae, 1992). The Big Five model (Goldberg, 1990) identifies "impulse control" as a feature of emotional stability (DeYoung et al., 2002). Whiteside and Lynam (2001) demonstrated that in the Big Five model, neuroticism is most directly related to impulsivity. Neuroticism comprises of several characteristics, such as negative affect, lack of the ability to control impulses, reactivity to stress, and inability to delay gratification. Hence, IBT may be considered as one expression of lack of control, stress reaction, and immediate gratification. Individuals who score high on lack of control are extemporaneous, reckless, careless, and even less expected to plan their activities. Thus, a generalised lack of control may be considered as a potential factor of IBT (Youn \& Faber, 2000). In addition, neurotic individuals possess negative emotional states (e.g., anxiety, depressed mood) under everyday life conditions, which may lead them to engage in behaviours (such as buying) that help them to escape from the negative emotional state or provide some relief at best. In brief, neurotic individuals incline towards immediate satisfaction of their desires and may have more difficulties with the feeling deprived by not buying something even when the corresponding product does not match their current needs. Studies by Bratko et al. (2013), Sun and Wu (2011), and Verplanken and Herabadi (2001) investigated the relationship between neuroticism and IBT. Bratko et al. (2013) and Leong et al. (2017) found a significant relationship. On 
the other hand, Russo et al. (2009) and Webster and Crysel (2009) reported mixed empirical findings regarding the neuroticism-general impulsivity relationship. Based on these arguments, we formulated the following hypotheses:

$\mathrm{H}_{2 \mathrm{a}}$ : Neuroticism may be positively related to IBT

$\mathrm{H}_{2 \mathrm{~b}}$ : Neuroticism may be positively related to product specific IBT

\section{Influence of Conscientiousness}

Conscientious individuals are willing to be in line with traditional rules, norms, and standards (Hogan \& Hogan, 2007). They are systematic, careful, cautious, and strive for achievement, competence, deliberation, disposition, dutifulness, and self-discipline. These individuals carefully plan their shopping trips and are less expected to buy unwanted items (Verplanken \& Sato, 2011). Conscientious individuals prefer to confine their impulses and possess a tendency to plan and control their behaviour (Carver et al., 1998). Hence, such characterised selfdiscipline traits of conscientious individuals should be negatively related to impulse buying and variety seeking. Researchers like Leong et al. (2017), Russo et al. (2009), and Verplanken and Herabadi (2001) affirm that there exists a negative bivariate correlation between conscientiousness and IBT. Bratko et al. (2013) found similar results, but conscientiousness and IBT were found to be unrelated when they performed a hierarchical regression analysis in which the Big Five personality factors were employed as uncorrelated factors. Generally, people with high conscientiousness plan their shopping trips judiciously and cautiously and hence have less tendency to purchase unneeded products (Verplanken \& Sato, 2011). On the other hand, studies like Mulyanegara et al. (2009) and Riza (2011) observed that conscientious individuals have a high affinity for buying the product which symbolically represents success and exclusivity. Hence, based on the above argument we hypothesised that:

$\mathrm{H}_{3 \mathrm{a}}$ : Conscientiousness will have a negative relation with IBT

$\mathrm{H}_{3 \mathrm{~b}}$ : Conscientiousness will have a relation with product specific IBT

\section{RESEARCH METHODOLOGY}

\section{Measurement of Constructs}

After the extensive review of literature, it was decided to use existing validated scales to measure responses of the selected constructs. The survey instrument 
comprised statements related to the three personality traits - extraversion, conscientiousness and neuroticism, and IBT. To examine these personality traits of buyers, Olsen et al. (2016) scales were used. These traits were presented by the heading "I see myself as someone who is," followed by a unipolar trait descriptive adjective. The scale developed by Rook and Fisher (1995) was adopted to assess the impulsive buying tendency among the sample respondents. To record the responses, a seven-point Likert's scale was used, where 1 and 7 signified "strongly disagree" to "strongly agree" respectively.

\section{Experimentation Procedure}

To identify the product category, it was decided that a pre-study with a sample of 22 participants ( 8 research scholars, 8 postgraduate students, and 6 working executives) is conducted. They were interviewed with respect to their online shopping and were requested to share the summary list of products purchased in the last six months. To figure out the product(s) they had bought impulsively, each of the study participants was interviewed in detail. From this activity, apparel emerged to be the most impulsively brought product category.

It was decided that a scenario-based online experiment would be undertaken. Further, to create a realistic experimental setting, a scenario of online purchasing context was built around the buying of summer coat. The situation involved a shopper with a plan to buy footwear from an online retailer. While browsing the portal, the shopper sees a summer coat. The respondents were expected to give their opinion regarding the shopper's final buying decision - footwear only, summer coat only, or both. This technique was employed with the assumption that respondents with impulsiveness will have more probability of indulging in impulsive buying (Rook \& Fisher, 1995). This scenario was briefed to the respondents of Group 2 only.

Using Qualtrics, the sample respondents were randomly categorised into two groups: Group 1 comprised respondents who were provided with an instrument to measure their impulse buying tendency in general without any reference to a specific product category; and Group 2 had respondents for whom the instrument was shared with a scenario, specifically, built around the product category of apparel. Consisting of just two groups, the study was administered online during March-June 2017. Finally, 386 respondents completed the survey - 194 for Group 1 and 192 for the product-specific group. In Group 1, 73\% of the respondents were males and $21 \%$ were married. The group had the second group had $75 \%$ respondents as males and nearly $78 \%$ were unmarried. 


\section{Results}

\section{Reliability of scales}

To assess the reliability of the constructs, Cronbach's alpha was calculated for both the samples. From Table 1, it is observed that the values of Cronbach's alpha for all the constructs in both the categories were above the cut-off level of 0.6 (Malhotra, 2008).

Table 1

Descriptive statistics for two groups

\begin{tabular}{llcccc}
\hline & & \multicolumn{2}{c}{ Without specific product category } & With specific product category \\
\hline Constructs & Items & Mean & Cronbach's $\alpha$ & Mean & Cronbach's $\alpha$ \\
\hline Extraversion & Three & 3.3333 & 0.642 & 3.6144 & 0.681 \\
Neuroticism & Three & 3.2925 & 0.754 & 3.5180 & 0.611 \\
Conscientious & Four & 3.9641 & 0.864 & 4.3775 & 0.843 \\
IBT & Nine & 4.4526 & 0.842 & 5.3930 & 0.842 \\
\hline
\end{tabular}

\section{Factor analyses}

Exploratory factor analysis was undertaken to determine the underlying factor structure. From the data of Group 1, one item ("I carefully plan most of my purchases") from the scale measuring impulse buying tendency was removed due to low communality value. As per Table 2, the results yielded the four-factor solution with an eigenvalue greater than 1.0 that accounted for $64.89 \%$ of the total variance explained.

Table 2

Factor analysis (without specific product category)

\begin{tabular}{lcccc}
\hline & \multicolumn{3}{c}{ Factor } \\
\hline Elements & IBT & Conscientious & Neuroticism & Extraversion \\
\hline "I see it, I buy it" describes me & 0.828 & & \\
$\begin{array}{l}\text { Sometimes I am a bit reckless about } \\
\text { what I buy }\end{array}$ & 0.819 & & & \\
$\begin{array}{l}\text { Sometimes, I feel like buying things } \\
\text { on the spur-of-the-moment }\end{array}$ & 0.806 & & \\
$\begin{array}{l}\text { "Just do it" describes the way I buy } \\
\text { things }\end{array}$ & 0.792 & & \\
\hline
\end{tabular}




\section{Chandan Parsad et al.}

Table 2. (continued)

\begin{tabular}{lcccc}
\hline & \multicolumn{3}{c}{ Factor } \\
\hline Elements & IBT & Conscientious & Neuroticism & Extraversion \\
\hline I often buy things without thinking & 0.768 & & & \\
"Buy now, think about it later" & 0.756 & & & \\
describes me & & & & \\
I often buy things spontaneously & 0.698 & & & \\
I buy things according to how I feel & 0.658 & & & \\
at that moment & & & & \\
Disorganised/careless (R) & & 0.876 & \\
Punctuality/systematic & & 0.845 & & \\
Messy/inaccurate (R) & & 0.7425 & 0.822 & \\
Dependable/self-disciplined & & 0.796 & \\
Nervous/tense & & 0.795 & \\
Calm/emotionally stable (R) & & & 0.805 \\
Anxious/easily upset & & & 0.738 \\
Outgoing/enthusiastic & & & 0.669 \\
Reserved/quiet (R) & & & \\
Chatty/talkative & & & \\
\hline
\end{tabular}

In Group 2 again, the same item ("I carefully plan most of my purchases") measuring IBT was removed owing to a low communality value. From Table 3, it is observed that the results yielded a four-factor solution with an eigenvalue greater than 1.0 , explaining $62.86 \%$ of the total variance.

Table 3

Factor analysis (with specific product category)

\begin{tabular}{lcccc}
\hline & \multicolumn{3}{c}{ Factor } & \\
\hline Elements & IBT & Conscientious & Neuroticism & Extraversion \\
\hline "I see it, I buy it" describes me & 0.817 & & \\
$\begin{array}{l}\text { Sometimes I am a bit reckless about } \\
\text { what I buy }\end{array}$ & 0.809 & & \\
$\begin{array}{l}\text { Sometimes, I feel like buying things } \\
\text { on the spur-of-the-moment }\end{array}$ & 0.788 & & \\
$\begin{array}{l}\text { "Just do it" describes the way I buy } \\
\text { things }\end{array}$ & 0.760 & & \\
I often buy things without thinking & 0.741 & & \\
\hline
\end{tabular}


Table 3. (continued)

\begin{tabular}{lcccc}
\hline & \multicolumn{3}{c}{ Factor } \\
\hline Elements & IBT & Conscientious & Neuroticism & Extraversion \\
\hline "Buy now, think about it later" & 0.701 & & & \\
describes me & & & & \\
I often buy things spontaneously & 0.687 & & & \\
I buy things according to how I feel at & 0.580 & & & \\
that moment & & & & \\
Disorganised/careless (R) & & 0.851 & \\
Punctuality/systematic & 0.844 & & \\
Messy/inaccurate (R) & 0.807 & & \\
Dependable/self-disciplined & 0.674 & & \\
Nervous/tense & & & 0.807 & \\
Calm/emotionally stable (R) & & 0.531 & 0.799 \\
Anxious/easily upset & & & 0.759 \\
Outgoing/enthusiastic & & & 0.745 \\
Reserved/quiet (R) & & & \\
Chatty/talkative & & & \\
\hline
\end{tabular}

\section{Evaluating the Hypothesised Model: Regression Analysis}

Using ordinary least squares (OLS) multiple regression, the hypotheses were tested for both the groups. The equation formulated:

$$
\mathrm{IBT}=\beta_{0}+\operatorname{Ext} \beta_{1}+\mathrm{Neu} \beta_{2}+\operatorname{Cons} \beta_{3}+e
$$

\section{Case 1: Testing $H_{1 a}, H_{2 a}$ and $H_{3 a}$ for Group 1 (without specific product category)}

With the values $\beta=0.144 ; \mathrm{t}=1.676$ (Table 4 ), it is noted that extraversion is positively related IBT. Thus, hypothesis $\mathrm{H}_{1 \mathrm{a}}$ is accepted. Again, with $\beta=0.183$ and $\mathrm{t}=2.255$, neuroticism is observed to have a significant relationship with impulsive buying tendency $\left(\mathrm{H}_{2 \mathrm{a}}\right)$. However, conscientiousness as a personality trait has been found to have the insignificant relationship with IBT, thus, hypothesis $\mathrm{H}_{3 \mathrm{a}}$ is rejected. 


\section{Chandan Parsad et al.}

Table 4

Regression results (without specific product category)

\begin{tabular}{lll}
\hline & Dependent variable & F (sig) \\
\hline Predictor variables & IBT & $5.037(0.002)$ \\
Extraversion & $0.144(1.676)^{* *}$ & \\
Neuroticism & $0.183(2.255)^{*}$ & \\
Conscientiousness & $0.093(1.068)$ & \\
$\mathrm{R}^{2}$ (Adjusted $\left.\mathrm{R}^{2}\right)$ & $0.092(0.074)$ & \\
\hline
\end{tabular}

Notes: *Regression is significant at the 0.05 level; ** Regression is significant at the 0.10 level

\section{Case 2: Testing $H_{1 b}, H_{2 b}$ and $H_{3 b}$ for Group 2 (with specific product category)}

From Table 5, the values of $\beta=0.315$ and $t=6.267$ indicate extraversion to be positively related to impulsive buying tendency. Thus, the hypothesis $\mathrm{H}_{1 \mathrm{~b}}$ is supported. Similarly, for hypothesis $\mathrm{H}_{2 \mathrm{~b}}$, we conclude that neuroticism is positively related to the tendency of impulsive shopping. Further, conscientiousness is also observed to have a significant relationship with the impulsive tendency $(\beta=0.467$; $\mathrm{t}=8.135)$.

Table 5

Regression results (with specific product category)

\begin{tabular}{lll}
\hline & Dependent variable & $\mathrm{F}($ sig $)$ \\
\hline Predictor variables & IBT & $201.358(0.000)$ \\
Extraversion & $0.315(6.267)^{*}$ & \\
Neuroticism & $0.226(4.214)^{*}$ & \\
Conscientiousness & $0.467(8.135)^{*}$ & \\
$\mathrm{R}^{2}$ (Adjusted $\left.\mathrm{R}^{2}\right)$ & $0.802(0.798)$ & \\
\hline
\end{tabular}

Notes: *Regression is significant at the 0.05 level

Thus, it is noted that the influence of conscientiousness on impulsive buying tendency is visible in the context of specific product categories as against no influence in case of a generic category. Also, for Group 2, the value of $\mathrm{R}^{2}$ (adjusted $\left.\mathrm{R}^{2}\right)=0.802(0.798)$ indicate that proposed model explains $80.2 \%$ of total variance. On the other hand, the model explains only $9.2 \%$ of the variance in case of general IBT. Hence, product-specific IBT is more indicative than that of general category. Also, it can be inferred that the specific category of a product greatly impacts shoppers' tendency to buy impulsively. 


\section{Independent t-test}

To test whether there is a significant difference between the two models, an independent $\mathrm{t}$-test was conducted. With $\mathrm{t}$ value 1.716 and $\mathrm{p}<0.10$, it is observed that the two models are statistically different (Table 6).

Table 6

Independent samples test

\begin{tabular}{llllllll}
\hline & & \multicolumn{2}{l}{$\begin{array}{l}\text { Levene's test for } \\
\text { equality of variances }\end{array}$} & & \multicolumn{3}{c}{ t-test for equality of means } \\
\cline { 2 - 7 } & $\mathrm{F}$ & Sig. & $\mathrm{T}$ & $\mathrm{df}$ & $\begin{array}{l}\text { Sig. } \\
\text { (2-tailed) }\end{array}$ & $\begin{array}{l}\text { Mean } \\
\text { difference }\end{array}$ \\
\hline IBT & $\begin{array}{l}\text { Equal variances } \\
\text { assumed }\end{array}$ & 16.161 & 0.000 & -1.716 & 304.00 & 0.087 & -0.94036 \\
$\begin{array}{l}\text { Equal variances } \\
\text { not assumed }\end{array}$ & & & -1.716 & 160.354 & 0.088 & -0.94036 \\
\hline
\end{tabular}

\section{DISCUSSION}

Existing studies on impulsive buying have identified various predictors that include age (Wong \& Ahuvia, 1998), gender (Dittmar et al., 1995), culture (Kacen \& Lee, 2002), and affect (Verplanken et al., 2005). Understanding the psychological aspects that arouse consumers to purchase has always fascinated the academicians, marketers, and retailers. There is always a need to decipher the influence of personality on impulsive shopping behaviour. Verplanken and Herabadi (2001) have explored the role of personality traits on such type of buying using Big Five Personality Traits. Later, Vohs and Faber (2003) studied the impact of self-control in inhibiting such sudden urges for shopping. The present study is an attempt to identify the influence of three prominent personality traits on the impulsive shopping tendency in two contexts - the tendency in general and the tendency in specific product scenario. The retailers may use the insights from this research to stir the shoppers' impulsive buying tendency in both online as well as offline context.

Interpreting the empirical results from the research, it is observed from the present study that the two traits - neuroticism and extraversion have the positive influence in triggering the impulsive tendency in the scenario where no specific product was mentioned. Conscientiousness, on the other hand, didn't have a negative influence on IBT, as was otherwise proposed. In case of the scenario with the specific product, 
all the three traits - neuroticism, extraversion, and conscientiousness were noted to have an influence on IBT.

With respect to neuroticism, the significant positive relationship affirms that shoppers with this negative emotion (trait) have a higher tendency to indulge in impulsive buying (Black, 2007; Faber \& O' Guinn, 2008; Verplanken \& Sato, 2011). These results are consistent with earlier findings that shoppers with neuroticism traits are impulsive (Vazire \& Funder, 2006; Miller et al., 2009). Cash and Cash (1982) observed that shoppers with high positive self-view are more likely to buy on impulse. The relationship between the trait of extraversion and impulsiveness can be explained on the bases of Carver and Scheier (2008), according to which individuals with this trait exhibit spontaneity and hence lack premeditation and planning.

Conscientiousness was found to have an insignificant effect on shoppers' impulsive tendency in the situation that measured general impulsiveness without reference to any specific product category. This is in contradiction with earlier studies like Bratko et al. (2013) and Olsen et al. (2016) that have posited the negative association between this personality trait and tendency to indulge in impulsive shopping. The possible reason that can be attributed in this case might be that the respondents could have engaged in reminder impulse purchasing in general, owing to influencers like promotional incentives, discounts, etc. On the other hand, in case of the product-specific (fashion apparel) scenario, the trait was noted to have a positive significant relationship with IBT. Accordingly, persons with a high score in conscientiousness will exhibit a higher tendency to buy impulsively. This result contradicts the earlier study by Olsen et al. (2016). Here, it must be noted that Olsen et al. (2016) was conducted to gauge the impact of the personality trait in general scenario as against a specific product scenario. As stated earlier, few studies like Mulyanegara et al. (2009) and Riza (2011) have observed that people with conscientiousness exhibit more impulsiveness for products that symbolically represent exclusiveness and/success. Hence, this might be one of the reasons for the positive relation between conscientiousness and IBT. Also, this finding calls for future research by analysing the influence of shoppers' conscientiousness across different product categories.

The most noteworthy result of the present study is the significant role of "specificity of product category" in creating an urge to buy impulsively. An earlier study by Jones et al. (2003) has observed that the general tendency of IBT is different from product-specific IBT. This finding is similar to the outcome of the present study. Hence, retailers should incorporate product-specific cues in marketing stimuli 
while attempting to draft their merchandising and promotional strategies aimed at inducing IBT among the target shoppers.

Another interesting aspect of the study pertains to the role the three traits in influencing the impulsive tendency. It is observed that in the first model (without any specific product category), the data sample explained only $9.2 \%$ of the total variance, and neuroticism has a higher influence than extraversion. However, in the later model with specific consideration of product category (apparel), the data set explained $82 \%$ of the total variance. Conscientiousness has a highest, but negative influence on IBT, implying that the presence of this trait acts as an inhibitor in triggering of such sudden urges. Between the two traits that have a positive influence on IBT, extraversion has a more significant role than neuroticism in predicting impulsiveness.

\section{Managerial Implications}

Generally, it is believed that shoppers' buying tendency is difficult to be predicted and analysed by simply observing their behaviour. Researches have indicated that shopping behaviour is a manifestation of the influence of various external stimuli like store environment, price of the product, in-store promotions, advertisements, and design and display of product, etc. Besides these, some unobservable emotional mechanisms such as buyers' motivations (approach or avoidance) of shopping, their perception towards the brand, product, retailers, etc., play a significant role. To overcome the issues in predicting individuals' impulsive tendency, some researchers have suggested that shoppers' personality traits may be used as a significant predictor(s) of such buying. Personality traits are a good input in analysing their behaviour, although there is a debate over the consistency of individual behaviour over different situations (Carver \& Scheier, 2008). Funder (2010) claimed that individuals with a particular personality trait tend to display consistency in their behaviour patterns in most of the situations.

The findings of this paper provide a path for better understanding, explanation, and prediction of impulsive buying behaviour. Based on the findings of past studies, this paper has used three personality traits for analysing the relationship between personality and individual's impulsive buying tendency in two different contexts - impulsive tendency without the mentioning of any product category, and the tendency with a specific product category. Thus, the results extend research-based cues for retailers desirous of understanding and exploiting shoppers' behavioural tendencies with sudden urges to buy. 
For example, the results demonstrate that neuroticism act as a significant driver for stimulating the IBT among shoppers irrespective of the product categories. Also, the paper observes that individuals with neuroticism trait have a high tendency of buying impulsively. This presents a good business opportunity for retailers and marketer. Characterised as self-centric and egoistic individuals, shoppers with neuroticism personality trait have more affinity for the symbolic value of products rather than the utilitarian value (Sedikides et al., 2007; Lee et al., 2013). A retailer may work upon the store environment in creating a positive mood, especially to target these specific groups. The marketers must design promotional campaigns for their product (services) and emphasise the creative content that pivots around mood repairing, positive emotion or mood enhancement appeal for affecting shoppers' moods and subsequently their impulsive buying behaviour.

Extraversion is another important personality trait that has an association with the impulsive tendency irrespective of the product category. Symbolised as an incentive salience buyer, these shoppers exhibit a tendency of compulsive purchasing and the amplified impulsive tendency of shopping. To influence individuals with such traits, marketers must focus on "desire to have" product (service) by linking the campaigns/ products with the bright side of life.

With respect to conscientiousness, the results show that individuals with this trait have an inverse affinity with impulsive buying, more specifically for the category of fashion apparel. Such buyers have a high tendency to plan their shopping lists. To influence the buying decision of these buyers, retailers must focus on the utilitarian aspects of the shopping, which might include a vast portfolio of products (product assortment). This shall help the shoppers in matching their product requirements with available choices, thereby increasing buying chances. This makes it pertinent for retailers to understand the trade-off between stock-out and inventory-carrying costs. The endeavour here should be to maximise the profit by maintaining a balance between the two costs. Overall, this study signifies that individuals high on neuroticism, extraversion, and less on conscientious are most likely to act impulsively.

\section{Limitations and Future Research}

As in the case of empirical studies, this study is also constrained with few limitations. Understanding these limitations shall pave a way for more research on the association between personality traits and impulse buying in both the contexts - product specific as well as the general setting, where no product category is specifically identified. Future research may include control mechanisms like 
"mood" as a moderating variable, as has been suggested by Chien-Huang and Hung-Chou (2012). This research was carried out by using a single product category. Future research may use different product categories, especially from varying levels of involvement (high and low involvement product category).

\section{REFERENCES}

Atulkar, S., \& Kesari, B. (2018). Role of consumer traits and situational factors on impulse buying: Does gender matter? International Journal of Retail \& Distribution Management, 46(4), 386-405. https://doi.org/10.1108/ijrdm-12-2016-0239

Beatty, S.E., \& Ferrell, M.E. (1998). Impulsive buying: Modeling its precursors. Journal of Retailing, 74, 169-191. https://doi.org/10.1016/s0022-4359(99)80092-x

Bellini, S., Cardinali, M.G., \& Grandi, B. (2017). A structural equation model of impulse buying behaviour in grocery retailing. Journal of Retailing and Consumer Services, 36, 164-171. https://doi.org/10.1016/j.jretconser.2017.02.001

Black, D.W. (2007). A review of compulsive buying disorder. World Psychiatry, 6, 14-18.

Bratko, D., Butkovic, A., \& Bosnjak, M. (2013). Twin study of impulsive buying and its overlap with personality. Journal of Individual Differences, 34(1), 8-14. https:// doi.org/10.1027/1614-0001/a000091

Carver, C.S., \& Scheier, M.F. (2008). Perspectives on personality, 6th ed. New York: Pearson.

Carver, C.S., Charles, S., \& Scheier, M.F. (1998). On the self- regulation of behavior. Cambridge: Cambridge University Press.

Cash, T.F., \& Cash, D.W. (1982). Women's use of cosmetics: Psychosocial correlates and consequences. International Journal of Cosmetic Science, 4(1), 1-14. https://doi. org/10.1111/j.1467-2494.1982.tb00295.x

Chang, C. (2010). Message framing and interpersonal orientation at cultural and individual levels: Involvement as a moderator. International Journal of Advertising, 29(5), 765-794. https://doi.org/10.2501/s0265048710201452

Chien-Huang, L., \& Hung-Chou, L. (2012). Effects of mood states on variety seeking: The moderating roles of personality. Psychology \& Marketing, 29, 157-166. https:// doi.org/10.1002/mar.20512

Chen, Y.F., \& Wang, R.Y. (2016). Are humans rational? Exploring factors influencing impulse buying intention and continuous impulse buying intention. Journal of Consumer Behaviour, 15(2), 186-197. https://doi.org/10.1002/cb.1563

Costa, P.T., \& McCrae, R.R. (1992). Four ways five factors are basic. Personality and Individual Differences, 13(6), 653-665. https://doi.org/10.1016/01918869(92)90236-i

Criteol. (2016). Browsing and buying behavior 2016. Study: US online consumer shopping behavior revealed. Retrieved 29 June 2017 from http:/www.criteo.com/ media/6449/criteo-resources-browsing-buying-behavior-q2-2016.pdf.

Dawson, S., \& Kim, M. (2009). External and internal trigger cues of impulse buying online. Direct Marketing, 3(1), 20-34. https://doi.org/10.1108/17505930910945714 
Dawson, S., \& Kim, M. (2010). Cues on apparel web sites that trigger impulse purchases. Journal of Fashion Marketing and Management, 14(2), 230-246.

DeYoung, C.G., Peterson, J.B., \& Higgins, D.M. (2002). Higher-order factors of the Big Five predict conformity: Are there neuroses of health? Personality and Individual Differences, 33(4), 533-552. https://doi.org/10.1016/s0191-8869(01)00171-4

Dittmar, H., Beattie, J., \& Friese, S. (1995). Gender identity and material symbols: Objects and decision considerations in impulse purchases. Journal of Economic Psychology, 16(3), 491-511. https://doi.org/10.1016/0167-4870(95)00023-h

Faber, R.J., \& O’Guinn, T.C. (2008). Compulsive buying: Review and reflection. In C.P. Haugtvedt, P.M. Herr, \& F.R. Kardes (Eds.), Handbook of consumer psychology (pp. 1039-1056). New York: Erlbaum.

Funder, D.C. (2010). The personality puzzle, 5th ed. New York: W.W. Norton \& Company. Global Banking \& Financial Review. (2016). How much are your impulse purchases costing you? Retrieved 15 January 2018 from https://www.globalbankingandfinance. com/how-much-are-your-impulse-purchases-costing-you/

Goldberg, L.R. (1990). An alternative "description of personality": The big-five factor structure. Journal of Personality and Social Psychology, 59(6), 1216-1229. https://doi.org/10.1037/0022-3514.59.6.1216

Heilman, C.M., Nakamoto, K., \& Rao, A.G. (2002). Pleasant surprises: Consumer response to unexpected in-store coupons. Journal of Marketing Research, 39(2), 242-252. https://doi.org/10.1509/jmkr.39.2.242.19081

Hogan, R., \& Hogan, J. (2007). Hogan Personality Inventory manual, 3rd ed. Tulsa, OK: Hogan Assessment Systems. https://doi.org/10.1037/t02029-000

Jones, M.A., Reynolds, K.E., Weun, S., \& Beatty, S.E. (2003). The product-specific nature of impulse buying tendency. Journal of Business Research, 56(7), 505-511. https://doi.org/10.1016/s0148-2963(01)00250-8

Johnson, J., \& Briggs, S. (Eds.). Handbook of personality psychology. San Diego, CA: Academic Press.

Judge, T.A., Higgins, C.A., Thoresen, C.J., \& Barrick, M.R. (1999). The big five personality traits, general mental ability, and career success across the life span. Personnel Psychology, 52(3), 621-652. https://doi.org/10.1111/j.1744-6570.1999.tb00174.x

Kacen, J.J., \& Lee, J.A. (2002). The influence of culture on consumer impulsive buying behavior. Journal of Consumer Psychology, 12(2), 163-176. https://doi. org/10.1207/s15327663jcp1202_08

Kassarjian, H.H., \& Sheffet, M.J. (1991). Personality and consumer behavior: An update. In H.H. Kassarjaian, \& T.S. Robertson (Eds.), Perspectives in consumer behavior, 4th ed. (pp. 281-303). Englewood Cliffs, NJ: Prentice Hall.

Kumar, H., Garg, R., Kumar, P., \& Chhikara, R. (2020). A qualitative insight into the personal factors impacting online impulse behavior. In R.C. Ho (Ed.), Strategies and tools for managing connected consumers (pp. 279-291). London: IGI Global. https://doi.org/10.4018/978-1-5225-9697-4.ch016

Leong, L.Y., Jaafar, N.I., \& Sulaiman, A. (2017). Understanding impulse purchase in Facebook commerce: Does Big Five matter? Internet Research, 27(4), 786-818. https://doi.org/10.1108/intr-04-2016-0107 
Lee, K., Ashton, M.C., Wiltshire, J., Bourdage, J.S., Visser, B.A., \& Gallucci, A. (2013). Sex, power and money. European Journal of Personality, 27(2), 169-184.

Lucas, M., \& Koff, E. (2014). The role of impulsivity and of self-perceived attractiveness in impulse buying in women. Personality and Individual Differences, 56, 111115. https://doi.org/10.1016/j.paid.2013.08.032

Malhotra, N.K. (2008). Marketing research: An applied orientation, 5th ed. Delhi: Pearson Education India.

Miller, J.D., Campbell, W.K., Young, D.L., Lakey, C.E., Reidy, D.E., Zeichner, A., \& Goodie, A.S. (2009). Examining the relations among narcissism, impulsivity, and self-defeating behaviors. Journal of Personality, 77(3), 761-794. https://doi. org/10.1111/j.1467-6494.2009.00564.x

Ming, C. (2017). Singles' Day: Alibaba smashes records at world's largest online shopping event. Retrieved 29 August 2017 from https:/www.cnbc.com/2016/11/11/ singles-day-news-alibaba-poised-to-smash-records-at-worlds-largest-onlineshopping-event.html.

Mulyanegara, R.C., Tsarenko, Y., \& Anderson, A. (2009). The Big Five and brand personality: Investigating the impact of consumer personality on preferences towards particular brand personality. Journal of Brand Management, 16(4), 234247. https://doi.org/10.1057/palgrave.bm.2550093

Nicholas, J.A., Li, F., Roslow, S., Kranendonk, C.J., \& Mandakovic, T. (2001). InterAmerican perspectives from mall shoppers: Chile-United States. Journal of Global Marketing, 15(1), 87-103. https://doi.org/10.1300/J042v15n01_06

Olsen, S.O., Tudoran, A.A., Honkanen, P., \& Verplanken, B. (2016). Differences and similarities between impulse buying and variety seeking: A personality based perspective. Psychology \& Marketing, 33(1), 36-47. https://doi.org/10.1002/ mar.20853

Parsad, C., Prashar, S., \& Vijay, S.T. (2017). Understanding nature of store ambiance and individual impulse buying tendency on impulsive purchasing behaviour: An emerging market perspective. Decision, 44(4), 297-311. https://doi.org/10.1007/ s40622-017-0168-2

Parsad, C., Prashar, S., \& Tata, V.S. (2019). Influence of personality traits and social conformity on impulsive buying tendency: Empirical study using 3M model. International Journal of Strategic Decision Sciences, 10(2), 107-124. https://doi. org/10.4018/ijsds.2019040106

Riza, M. (2011). The effects of consumer personality on fashion consciousness and prestige sensitivity. In Z. Yi, J.J. Xiao, J. Cotte, \& L. Price (Eds), Asia-pacific advances in consumer research, vol. 9 (pp. 336-339). Duluth, MN: Association for Consumer Research.

Robinson, T.E., \& Berridge, K.C. (1993). The neural basis of drug craving: An incentivesensitization theory of addiction. Brain Research Reviews, 18, 247-291. https:// doi.org/10.1016/0165-0173(93)90013-p

Rook, D.W. (1987). The buying impulse. Journal of Consumer Research, 14, 189-199.

Rook, D.W., \& Fisher, R.J. (1995). Normative influences on impulsive buying behavior. Journal of Consumer Research, 22(3), 305-313. https://doi.org/10.1086/209452 
Rook, D.W., \& Gardner, M.P. (1993). In the mood: Impulse buying's affective antecedents. Research in Consumer Behavior, 6(7), 1-28.

Rook, D.W., \& Hoch, S.J. (1985). Consuming impulses. Advances in Consumer Research, $12,23-27$.

Russo, N., Nicol, T., Trommer, B., Zecker, S., \& Kraus, N. (2009). Brainstem transcription of speech is disrupted in children with autism spectrum disorders. Developmental Science, 12(4), 557-567. https://doi.org/10.1111/j.1467-7687.2008.00790.x

Saran, R., Roy, S., \& Sethuraman, R. (2016). Personality and fashion consumption: A conceptual framework in the Indian context. Journal of Fashion Marketing and Management, 20(2), 157-176. https://doi.org/10.1108/jfmm-04-2015-0032

Sarabia-Sanchez, F.J., De Juan Vigaray, M.D., \& Hota, M. (2012). Using values and shopping styles to identify fashion apparel segments. International Journal of Retail \& Distribution Management, 40(3), 180-199. https://doi. org/10.1108/09590551211207157

Sedikides, C., Gregg, A.P., Cisek, S., \& Hart, C.M. (2007). The I that buys: Narcissists as consumers. Journal of Consumer Psychology, 17(4), 254-257.

Silvera, D.H., Lavack, A.M., \& Kropp, F. (2008). Impulse buying: The role of affect, social influence, and subjective wellbeing. Journal of Consumer Marketing, 25(1), 23-33. https://doi.org/10.1108/07363760810845381

Sen, A., \& Dalal, M. (2016). Flipkart outsells Amazon during festive sale. Retrieved 29 August 2017 from http://www.livemint.com/Companies/ fWmdwrhLeDBcDQcw50aUbO/Flipkart-outsells-Amazon-during-festive-sale. html.

Sharma, P., Sivakumaran, B., \& Marshall, R. (2010). Impulse buying and variety seeking: A trait-correlates perspective. Journal of Business Research, 63(3), 276-283. https://doi.org/10.1016/j.jbusres.2009.03.013

Stern, H. (1962). The significance of impulse buying today. The Journal of Marketing, 26(2), 59-62.

Sun, T., \& Wu, G. (2011). Trait predictors of inline impulsive buying tendency: A hierarchical approach. Journal of Marketing Theory and Practice, 19(3), 337346. https://doi.org/10.2753/mtp1069-6679190307

Thompson, E.R., \& Prendergast, G.P. (2015). The influence of trait affect and the five-factor personality model on impulse buying. Personality and Individual Differences, 76, 216-221. https://doi.org/10.1016/j.paid.2014.12.025

Vazire, S., \& Funder, D.C. (2006). Impulsivity and the self-defeating behavior of narcissists. Personality and Social Psychology Review, 10(2), 154-165. https:// doi.org/10.1207/s15327957pspr1002_4

Verplanken, B., \& Herabadi, A. (2001). Individual differences in impulse buying tendency: Feeling and no thinking. European Journal of Personality, 15(S1), S71-S83. https://doi.org/10.1002/per.423

Verplanken, B., \& Sato, A. (2011). The psychology of impulse buying: An integrative self-regulation approach. Journal of Consumer Policy, 34, 197-210. https://doi. org/10.1007/s10603-011-9158-5 
Verplanken, B., Herabadi, A.G., Perry, J.A., \& Silvera, D.H. (2005). Consumer style and health: The role of impulsive buying in unhealthy eating. Psychology \& Health, 20(4), 429-441. https://doi.org/10.1080/08870440412331337084

Vohs, K., \& Faber, R. (2003). Self-regulation and impulsive spending patterns. Advances in Consumer Research, 30, 125-126.

Watson, D., \& Clark, L.A. (1997). Extraversion and its positive emotional core. In R. Hogan, J.A. Johnson, \& S.R. Briggs (Eds.), Handbook of personality psychology (pp. 767-793). San Diego, CA: Academic Press.

Webster, G.D., \& Crysel, L.C. (2012). Hit me, maybe, one more time: Brief measures of impulsivity and sensation seeking and their prediction of blackjack bets and sexual promiscuity. Journal of Research in Personality, 46(5), 591-598.

Whiteside, S.P., \& Lynam, D.R. (2001). The five factor model and impulsivity: Using a structural model of personality to understand impulsivity. Personality and Individual Differences, 30(4), 669-689.

Wong, N.Y., \& Ahuvia, A.C. (1998). Personal taste and family face: Luxury consumption in Confucian and Western societies. Psychology \& Marketing, 15(5), 423-441.

Youn, S., \& Faber, R.J. (2000). Impulse buying: Its relation to personality traits and cues. Advances in Consumer Research, 27, 179-185. 